\title{
O.V. Gorbunova, H.V. Zarichanska Efficiency of using antifungal drugs in women with vaginal candidiasis on the background of papillomavirus infection
}

Shupyk National Medical Academy of Postgraduate Education, Kyiv, Ukraine

PERINATOLOGY AND PEDIATRIC. UKRAINE. 2018.2(74):31-34; doi 10.15574/PP.2018.74.31

According to the sources, vaginal candidiasis develops on the background of papillomavirus infection in $36-41 \%$ of cases. The violation of the vaginal biocenosis decreases the immunological potential of the epithelium, and creates favourable conditions for the carcinogenic effect of the human papillomavirus. We have examined 100 patients (18-40 years old) in order to evaluate the efficiency and safeness of Fluzamed (active ingredient: Fluconazole-150 mg) usage in treatment of vulvovaginal candidiasis with cervical dysplasia caused by papillomavirus infection. The treatment control was performed three times: after the first course of treatment, in 3 and 6 months. The study has shown that due to Fluconazole-150 mg treatment, the disease recurrences at 3 and 6 months were occurred significantly rarely as compared to the cases of Butoconazole- $20 \mathrm{mg} / \mathrm{g}$ application. The complete eradication of PVI was clinically and laboratory confirmed after 3 and 6 months of treatment. In our study, we have confirmed the safety of a systemic drug Fluzamed (active ingredient: Fluconazole-150 mg) usage by the lack of adverse reactions after its administration.

Key words: vaginal candidiasis, papillomavirus infection, Fluzamed.

\section{Ефективність використання антимікотичних препаратів у жінок із вагінальним кандидозом на тлі папіломавірусної інфекції \\ О. В. Горбунова, Х. В. Зарічанська \\ Національна медична академія післядипломної освіти імені П.Л. Шупика, м. Київ, Україна}

За даними літератури, вагінальний кандидоз розвивається на тлі папіломавірусної інсекції у 36-41\% випадках. При цьому відомо, що порушення біоценозу піхви знижують імунологічний потенціал епітелію і створюють реальні умови для канцерогенного ефекту вірусу папіломи людини (ВПЛ). 3 метою оцінки ефективності та безпечності препарату «Флузамед» (діюча речовина: Fluconazole-150 мг) у схемах лікування кандидозного вульвовагініту в поєднанні з дисплазією шийки матки, викликаною папіломавірусною інфекцією, було обстежено 100 пацієнток у віці $18-40$ років. Контроль лікування проводився тричі: після першого курсу лікування, через 3 місяці і через 6 місяців. Дослідження показало, що клінічний ефект після проведеного лікування препаратом Fluconazole-150 мг полягав у наступному: рецидиви захворювання через 3 та 6 місяців виникали достовірно рідше, ніж після застосування Butoconazol-20 мг/г. Повна елімінація ВПЛ була підтверджена клінічно та лабораторно через 3 місяці: у 27,0\% пацієнток | групи групи та 17,0\% пацієнток I| групи групи; через 6 місяців: у 58,0\% пацієнток I групи групи та 49,0\% пацієнток II групи групи. Безпечність застосування системного препарату «Флузамед» (діюча речовина: Fluconazole-150 мг) підтверджується відсутністю побічних реакцій після його застосування в нашому дослідженні.

Ключові слова: вагінальний кандидоз, папіломавірусна інфекція, Флузамед.

\section{Эффективность использования противогрибковых препаратов}

\section{у женщин с вагинальным кандидозом на фоне папилломавирусной инфекции}

\section{О. В. Горбунова, Х. В. Заричанская}

Национальная медицинская академия последипломного образования имени П. Л. Шупика, г. Киев, Украина

Резюме. По данным литературы, вагинальный кандидоз развивается на фоне папилломавирусной инфекции в 36-41\% случаях. При этом известно, что нарушения биоценоза влагалища снижают иммунологический потенциал эпителия и создают реальные условия для канцерогенного эффекта вируса папилломы человека (ВПЧ).

С целью оценки эфффективности и безопасности препарата «Флузамед» (действующее вещество: Fluconazole-150 мг) в схемах лечения кандидозного вульвовагинита в сочетании с дисплазией шейки матки, вызванной папилломавирусной инфекцией, было обследовано 100 пациенток в возрасте 18-40 лет. Контроль лечения проводился трижды: после первого курса лечения, через 3 месяца и через 6 месяцев. Исследование показало, что клинический эффект после проведенного лечения Fluconazole-150 мг заключался в следующем. Рецидивы заболевания через 3 и 6 месяцев возникали достоверно реже, чем после применения Butoconazol-20 мг/г. Полная элиминация ВПЧ была подтверждена клинически и лабораторно через 3 месяца: у 27,0\% пациенток І-й группы и у 17,0\% пациенток II-й группы; через 6 месяцев: у 58,0\% пациенток І-й группы и у 49,0\% пациенток II-й группы. Безопасность применения системного препарата «Флузамед» (действующее вещество: Fluconazole-150 мг) подтверждается отсутствием побочных реакций после применения в нашем исследовании.

Ключевые слова: вагинальный кандидоз, папилломавирусная инфекция, Флузамед.

Vaginal candidiasis is one of the most common women diseases. Large-scale research has shown that $3 / 4$ of world female population have experienced vaginal yeast infection at least once in their lifetime, $1 / 4$ of female population are concerned about the discharge caused by fungi of Candida spp., and $5-10 \%$ of females suffer from chronic forms of candidiasis [1,3]. We should also have in mind the fact that every fifth woman considers as an asymptomatic carrier of fungal infection $[2,5]$.

As for today, there are about a hundred known Candida species (C.). Among them
C. albicans, C.tropicalis, C.pseudotropicalis, C. krusei, C. parakrusei, C. parapsilosis, C. Guillermondi are patogenic for a human. They have a pronounced enzymatic activity and ability to produce proteolytic and lipolytic enzymes. These properties cause their high adhesion and deep penetration in the vaginal epitheliocytes $[3,6]$.

Papillomavirus infection (PVI) of the genital tract is one of the most common sexually transmitted infections (STIs). It is considered to be the leading factor of cervical carcinogenesis [5]. 
More than 290 millions of women in the world are infected with papilloma viruses [3].

Based on the recent medical research, 50-70\% of sexually active adults in the world are infected with PVI. At the same time, only $\mathbf{1 - 2 \%}$ has the clinical signs. The largest annual increase of PVI rate is observed among young people aged from 14 to 24 years [3].

Abnormal vaginal biocenosis reduces the immune potential of the epithelium, and creates conditions for the carcinogenic effect of the human papillomavirus (PVI) [6].

According to the sources, vaginal candidiasis develops on the background of papillomavirus infection in $36-41 \%$ of cases, but the problem of combination of these two infections is not fully investigated yet. That is why we decided to study the possibilities of modern medical therapy of vaginal candidiasis caused by papillomavirus infection.

The key aim of the study is to evaluate the efficiency and safety of the agent Fluzamed (active substance: Fluconazole) in the treatment of women at the stage of preconception care suffering from vulvovaginal candidiasis combined with cervical dysplasia caused by papillomavirus infection.

We have defined the next tasks:

1. To study the etiological agent of vaginal candidiasis in women with cervical dysplasia caused by papillomavirus infection.

2. To study the clinical efficiency of Fluzamed (active substance: Fluconazole-150 mg) as compared to Butoconazole-20 mg/g during follow-up monitoring in 3 and 6 months.

3. To evaluate the safety of systemic drug Fluzamed as compared to locally acting Butoconazole- $20 \mathrm{mg} / \mathrm{g}$.

According to our key aim and tasks, in total 100 women aged $18-40$ years were examined, suffering from colpitis of fungal etiology combined with cervical dysplasia caused by papillomavirus infection. The treatment included administration of Fluzamed (active substance: Fluconazole-150 mg) compared to the locally acting Butoconazole- $20 \mathrm{mg} / \mathrm{g}$.

All patients were divided into two groups: group I (basic) that comprised $\mathbf{5 0}$ women who were treated for colpitis of fungal etiology combined with cervical dysplasia caused by papillomavirus infection with Fluconazole-150 $\mathbf{~ m g}$; and group II (comparison) included $\mathbf{5 0}$ women who were treated for candidal colpitis combined with dysplasia of the cervix caused by papillomavirus infection with Butoconazole-20 $\mathrm{mg} / \mathrm{g}$.
Exclusion criteria: existence of severe extragenital pathology, which was as follows:

- diabetes;

- uncompensated pathological conditions of the liver;

- chronic and acute renal failure;

- hypersensitivity to fluconazole or other azole compounds, or to any excipients of the drug.

Research duration: 6 months.

During the first visit, the next diagnostic procedures were carried out, including:

- assessment of the nature of vaginal discharge, duration of symptoms, concomitant symptoms, sexual contacts during the last 12 months, contraceptive methods, results of the last preventive examination;

- history taking (anamnesis vitae, gynecological, reproductive, family, allergic history, hereditary background);

- objective clinical and laboratory examination.

Laboratory diagnostics included comprehensive evaluation of vaginal microbiocenosis: the microscopy of Gram-stained vaginal smears, bacteriological examination of the type of fungus and sensitivity to antimycotic drugs; liquid cytology and quantification of PVI after the disappearance of clinical and laboratory signs of candidiasis.

It is important to mention that it is still problematic to identify the etiology of the disease and to detect a significant number of infected people without laboratory diagnostics.

Diagnostic procedures during the follow-up visits included:

- control of the clinical symptoms in dynamics;

- control of bacterioscopic examination;

- simple and extended colposcopy;

- cervical biopsy based on medical indications;

- cytological research;

- quantitative determination of high-oncogenic genotypes of PVI.

In our study, we have used the syndromic approach that is scientifically substantiated, and offers affordable, immediate and effective treatment.

Treatment control was conducted 3 times: after the first course of treatment, in 3 and 6 months.

Treatment efficiency criteria:

- positive clinical effect - absence of symptoms and clinical signs of the disease;

- positive microbiological effect the absence of the causative agent. 
Clinical efficiency included the next terms:

1. Recovery - the absence of complaints and clinical signs of the disease with negative laboratory results.

2. Improvement - reduction or disappearance of complaints when the microbiological changes remain the same.

3. No changes - the constancy of clinical and laboratory signs after the treatment course.

4. Relapse of the disease - the restoration of clinical and laboratory signs of vaginal candidiasis after a full recovery within the period of 1-6 months since the onset of therapy.

The safety of drugs was evaluated based upon the presence of adverse reactions.

Results and discussion. The average age of the examined women was $24.6 \pm 1.2$ years. In most women $(85.0 \%)$, menstruation began at the age of $13-14$ and was regular. Only $15.0 \%$ of patients reported a history of menstrual irregularities. Anamnestic data showed that in the structure of inflammatory diseases of female genital organs prevailed the following: colpitis (70.0\%), salpingoophoritis (30.0\%), endometritis (10.0\%). In $14.0 \%$ of patients, infertility was noted.

In the reproductive anamnesis of patients, there was noted:

- pregnancy - in $65.0 \%$ cases;

- woman who has given birth once - in $28.0 \%$ of cases;

- among those who have given birth, threatened miscarriage in $60.0 \%$ of patients and spontaneous abortion in $14.0 \%$;

- stillbirth - in $2.0 \%$ of patients.

The dissonance between microbiological and clinical signs of vaginal candidiasis caught our attention. Ninety percent of patients presented with vaginal discharge. However, during the objective examination the excessiveness of the discharge was confirmed only in $75.0 \%$ of patients. In $60.0 \%$ of women from two groups were noted hyperemia and swollen vaginal mucosa. However, the microscopic examination revealed the increase of white blood cells in $100.0 \%$ of the examined women.

The obtained data showed that the mild or moderate dysplasia of cylindrical epithelium (according to the Bethesda system, ASC-US 'Atypical Squamous Cells of Undetermined Significance', squamous cell anemia of unknown genesis) was more often observed in women aged 18 to 25 years $(61.0 \%)$. The PVI test found a predominance of the 16th, 18th, 31st and 52nd types.
Table 1

\begin{tabular}{|c|c|c|}
\multicolumn{2}{|c|}{ Candida spp. Sensitivity to Antimycotic Drugs } \\
\hline $\begin{array}{c}\text { Candida } \\
\text { species }\end{array}$ & $\begin{array}{c}\text { Sensitive to } \\
\text { Fluconazole, } \\
\%\end{array}$ & $\begin{array}{c}\text { Sensitive to } \\
\text { Butoconazole, } \\
\%\end{array}$ \\
\hline C. albicans & 98.8 & 95.5 \\
\hline C. krusei & 75.0 & 50.0 \\
\hline C. tropicalis+C. albicans & 100.0 & 100.0 \\
\hline
\end{tabular}

According to the histological examination, CIN-I was diagnosed in $86.0 \%$ of women; CIN-II - in $14.0 \%$ of examined patients.

In our study, the types of Candida spp. were as follows:

- C. albicans - $90.0 \%$;

- C. krusei-8.0\%;

- combination of $C$. albicans with other types $-2.0 \%$.

The assessment of the sensitivity to antimycotic drugs is shown in Table 1.

Prior to initiating therapy, women participating in our study noted the following symptoms:

- vaginal discharge $-75.0 \%$;

- hyperemia and swollen vaginal mucosa $60.0 \%$

- dysuria - $15.0 \%$.

We have estimated the rate of clinical symptoms disappearance during the first 72 hours (Fig. 1).

Despite the fact that the clinical effect when using topical antifungal agent developed faster as compared to systemic drug administration, in our study the disease recurrences at 3 and

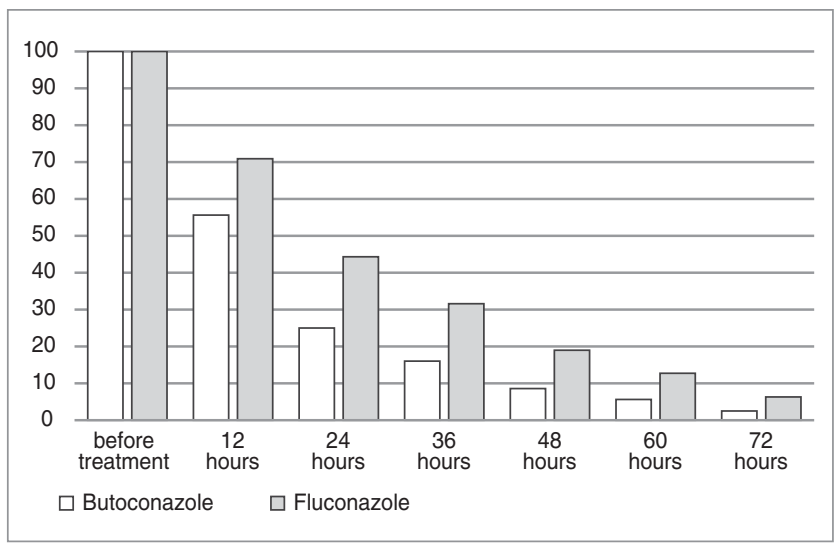

Fig. 1. Dynamics of clinical symptoms disappearance

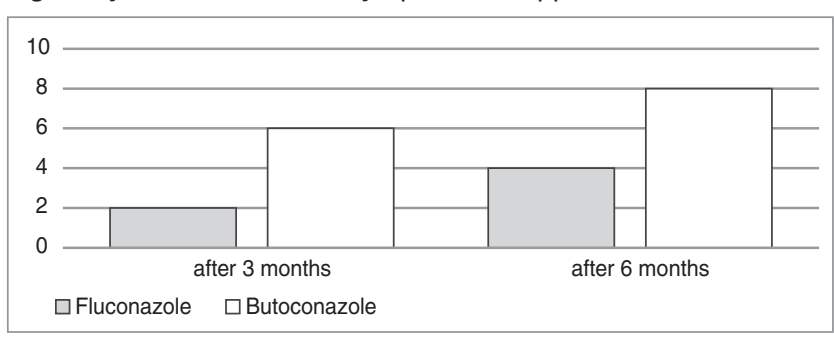

* - the difference between the indices of the basic group and the comparison group $(\mathrm{p}<0.05)$

Fig. 2. Vaginal candidiasis recurrences, \% 


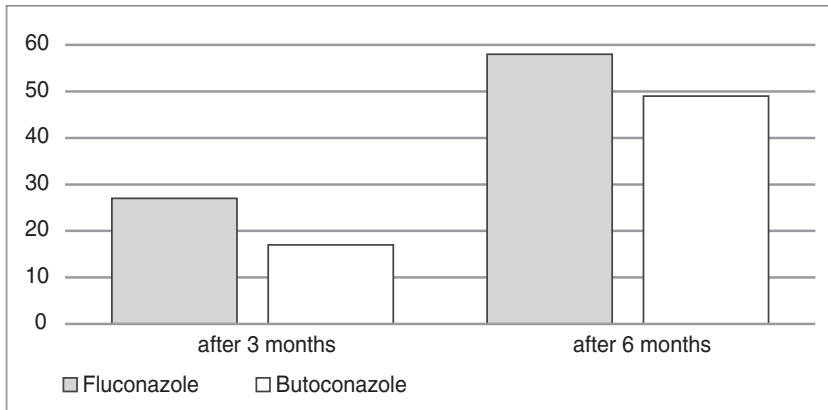

Fig. 3. Dynamics of PVI eradication, \%

6 months were occurred significantly rarely with Fluconazole-150 mg than Butoconazole- $20 \mathrm{mg} / \mathrm{g}$.

After vaginal candidiasis treatment completion, we have pointed out the full eradication of PVI. It was also clinically and laboratory proved in $27.0 \%$ of cases in group I and $17.0 \%$ of cases in group II after 3 months of treatment, and after 6 months of treatment in $58.0 \%$ of cases in group I and in $49.0 \%$ of cases in group II.

Side effects with Fluconazole-150 mg were not found, while with Butoconazole-20 mg/g, a local allergic reaction occurred in 1 case $(2.0 \%)$.

\section{Conclusions}

1. In our study, the most common pathogens of vaginal candidiasis were commensals Candida spp., which were as follows: C. albicans $-90.0 \%$; C. krusei $-8.0 \%$; combination of $C$. albicans with other types $-2.0 \%$.

2. The clinical effect of antifungal drug of local action Butoconazole- $20 \mathrm{mg} / \mathrm{g}$ developed faster. However, the clinical effect with Fluconazole-150 mg treatment was manifested in the significantly rare disease recurrences at 3 and 6 months than after the using of Butoconazole- $20 \mathrm{mg} / \mathrm{g}$. The full eradication of PVI was clinically and laboratory confirmed after 3 months treatment in $27.0 \%$ of patients in group I and $17.0 \%$ of patients in group II; after 6 months in $58.0 \%$ of patients in group I and $49.0 \%$ of patients in group II.

3 . The safety in the use of systematic agent Fluzamed (active substance: Fluconazole-150 mg) was confirmed by the lack of adverse reactions after its administration in our study, while Butoconazole-20 mg/g application caused a local allergic reaction in 1 patient $(2.0 \%)$.

Conflict of Interest: No conflict of interest was declared by the authors.

\section{REFERENCES}

1. Voronenko Y.V., Shekera O.G., Vdovychenko Y.P. (2016). Topical issues of obstetrics in the practice of a family doctor. Manual for intern doctors and doctorsstudents of institutions (faculties) of postgraduate education. Edited by Y.V. Voronenko, O.G. Shekera, Y.P. Vdovychenko. «Family Medicine» series. Kyiv.: Publisher O.Y. Zaslavskyi: 346.

2. Portal Consilium Medicum: http://con-med.ru/magazines/gynecology/gynecology-03-2002/ bakterialnyy_vaginoz_i_papillomavirusnaya_ infektsiya/?t_fieldset=SOCSERV
3. Kira E.F., Muslimova S.Z. (2008). Nonspecific vaginitis and its effect on the reproductive health of a woman (literature review). Reproduction problems. 5: 8-13.

4. Radzinskyi V.E., Khamoshina M.B., Kaigorodova L.A. at al. (2014). Correction of violations of the biocenosis of the vagina: march in place or moving forward? Reproductive Endocrinology. 4(18): 92-100.

5. Donders G.G., Bellen G., MendlingW. (2010). Management of reccurent vulvovaginal candidosis as a chronic illness. Gynec Obstet Inv. 4(70): 234-249.

6. Ravel J., Gajer P., Abdo Z. et al. (2011). Vaginal microbiome of reproductive-age women. Proc Natl Acad Scien USA. 108; 1: 4680-7.

\section{Сведения об авторах:}

Горбунова Ольга Владимировна - д.мед.н., доц., зав. каф. акушерства, гинекологии и перинатологии НМАПО имени П.Л. Шупика.

Адрес: г. Киев, ул. Дорогожицкая, 9; +38(044)205-49-46.

Заричанская Христина Владимировна - к.мед.Н., доц. каф. акушерства, гинекологии и перинатологии НМАПО имени П.Л. Шупика.

Адрес: г. Киев, ул. Дорогожицкая, 9; +38(044)205-49-46.

Статья поступила в редакцию 18.01 .2018 г. 


\section{Флузамед}

\section{ГРИБОК ТУРБУЄ - ФЛУЗАМЕД ЛІКУЄ}

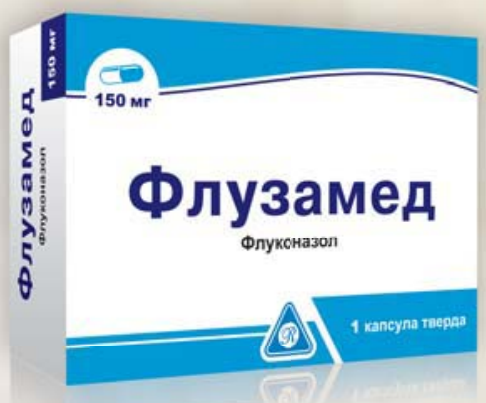

- Протигрибковий засіб системного застосування'

- Показаний при генітальному кандидозі'

- Разове застосування при неускладненому кандидозі ${ }^{1,2}$

${ }_{1}^{1}$ Інструкція для медичного застосування препарату Флузамед.
${ }^{2}$ Савицкая В.М., Коршикова Р.Л., Вербицкая М.С. Урогенитальный кандидоз: современный взгляд на проблему. // Репродуктивное здоровье. Восточная Европа. - 2012. - №5 (23).

\section{ПIМЕНДА 'sonomom \\ 1 раз на добу}

Метронідазол 750 мг / Міконазол 200 мг

- Протигрибкова дія

- Антибактеріальний та антитрихомонадний ефект

- Можливість застосування з 2-го триместру вагітності'

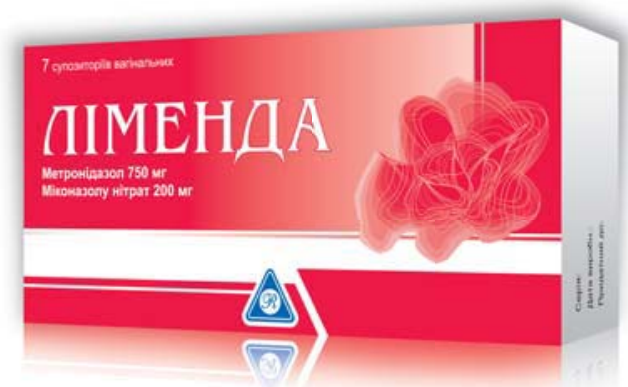

Флузамед. Склар: 1 капсула тверда містить флуконазолу 150 мг. Лікарська форма. Капсули тверді. Протигрибковий засіб для системного застосування. Селективний інгібітор грибкових ферментів, необхідних для синтезу ергостеролу. Показання

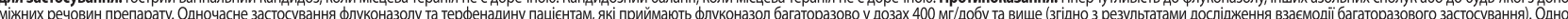
часне застосування флуконазолу та іншихлікарських засобів, що подовжують інтервал QТ та метаболізуються за допомогою ферменту СүРзА4. Можливі побічні ефекти, в тому числі головний біль, біль учеревній порожнині, діарея, нудота, блювання, висипання. Особливості застосування. Препарат містить лактозу. Діти. Ефективність та безпечність застосування препарату для лікуввання генітальних кандидозів у дітей не встановлені, незважаююии на вичерпні дані щодо застосуванняя препарату

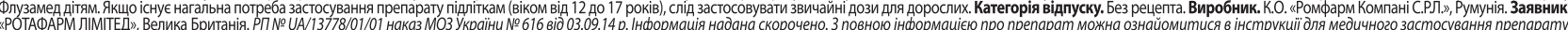
ннформація для медичних та фармацевтичних праиівників, а такождля розповсюдження в рамках спеціалізованихзаходвз зеедичноі тематики.

Ліменда. Склад: 1 супозиторій містить 750 мг метронідазолу та 200 мг міконазолу нітрату. Лікарська форма. Супозиторії вагінальні. Фармакотерапевтична група. Протимікробні та антисептичні засоби, що застосовуються у гінекології. похідних, порфірія, епілепсія, Іяжкі порушення функціпечінки. Побічні реакції. Частота виникнення системних побічних реакцій є незначною через дуже низький рівень метронідазолу у плазмі при вагінальному застосуванні препарату (2-

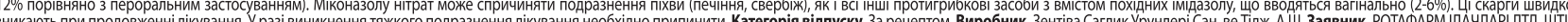

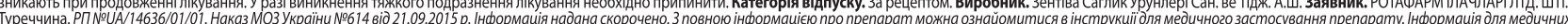

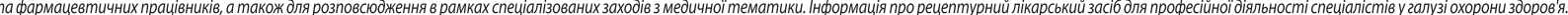

